\title{
Exploring the Impact of Service Quality on Commitment and Customer Loyalty in Jakarta's 3- Star Hotels
}

\author{
Eliza Simanjuntak, Theodosia C. Nathalia \\ Hospitality Management \\ Pelita Harapan School of Hospitality and Tourism \\ Tangerang, Indonesia \\ simanjuntak_eliza@yahoo.com
}

\author{
Yustisia Kristiana \\ Travel Industry Management \\ Pelita Harapan School of Hospitality and Tourism \\ Tangerang, Indonesia \\ theodosia.nathalia@uph.edu
}

\begin{abstract}
This study will specialize discussion in hotel business sector, particularly the 3-star hotels in Jakarta. 3-star hotels getting tough competition from budget hotels that continue to emerge in Jakarta and surrounding areas. Increased competition in the service industry for causing a company to be very concerned in terms of acquiring and retaining customers. Customer complaints is also the reason research in a 3-star hotels, in addition to the emergence of a budget hotel which adds competition within 3-star hotels. The paper aim to examine and explain the variable service quality, commitment, customer loyalty and influence between these variables. Design/methodology/approach: The unit of analysis in this research is the organization, 3-star hotels in Jakarta. The data collected data through a structured questionnaire based on the review of relevant literatures and an overview of the theories. Data were analyzed using SEM (Structural Equation Modeling). Findings: There is a positive influence of service quality on customer loyalty. They have a strong emotional attachment to the hotel that provides the right services, quickly, in accordance with promised and will promote it among friends, family and colleagues. There is a positive influence of the service quality on commitment. Hotel employees who look neat, show sincerity to help make customers feel an emotional bond, being concerned with the success of the hotel, have a sense of belonging, stayed at the hotel because of the need and hard to stay at another hotel. There is a positive influence of commitment on customer loyalty. Hotels that form a strong emotional bond so customers will choose this hotel brands and do not want to stay at another hotel. Originality/value: Commitment appropriately used in the context of a 3-star hotel to be able to induce customer loyalty, to see the positive influence on the relations to customer loyalty.
\end{abstract} loyalty

Keywords-3-star hotel, service quality, commitment, customer

\section{INTRODUCTION}

Hotel became one of the subject property as a prospective investment land for developers, domestic and abroad. World economic growth is more stable participate increasing number of middle-class people to make traveling activity continues to increase and the need for accommodation is increasing. A report released by Global Construction Pipeline Star recently said, China is the country that most hotel building. The countries listed are building 145,167 of the 452 hotel rooms. Indonesia itself become the fourth largest country in the Asia Pacific in the construction of the hotel in June 2015. In the period, total rooms built reach as many as 554,532 units of the 2,363 hotel. Meanwhile, two other states that fall into the top four was India $(26,159$ of the 158 hotel rooms) and Malaysia $(10,806$ out of 39 hotel rooms). Increased construction of hotel rooms in the Asia Pacific region reached approximately $6.7 \%$ when compared to the same period a year earlier. Incessant construction of the hotel was also felt in Indonesia as the growth of the national tourism industry is considered prospective. In Indonesia, there were as many as 27,243 of the 148 hotel rooms (Hanggara, 2015).

According to the Central Statistics Agency (BPS), in Indonesia the field of hotel business growth and contribute to the Gross Domestic Product (GDP) and employment. Thus the role increasingly important field of hotel business. So it can be seen in their role provide accommodation for guests (BPS, 2015). Hotel sector's contribution to GDP amounting to 16,230 (in billions of rupiah) in 2010 and 23,059 (in billions of rupiah) in 2014. During the period 2010-2014, the amount of GDP has increased. In addition to making a positive contribution to GDP, the labor sector in the areas of the hotel from 2010 to 2014 in particular continued to increase the amount of labor, i.e. labor from $14,300,819$ in 2010 to $18,935,707$ labor force in 2014.

Research in the field of hotel business was conducted in Jakarta based on two things. First, Jakarta is the largest metropolitan city in Indonesia. According to the Board of Investment and Promotion (BPMP), Jakarta about 28 million people is the largest metropolitan in Indonesia, even the order of all six of the world, and is the center of economic activity and the main gate of Indonesia. Second, growth and growth targets Gross Regional Domestic Product (GDP) in Jakarta, increased from 1.105 trillion in 2012 to 1.255 trillion rupiah in 2013. Target PDRB Jakarta in 2017 also increased to 1.337 trillion rupiah. This indicates that the GDP growth in Jakarta is getting better by the year 2017. According to BPMP (2015), Jakarta has a good economic growth, abundant resources, and 
is a comfortable city to perform various activities. Thus it can be assumed that the rate of visits to Jakarta with various purposes, will also increase. This indicates the need for a temporary shelter as the hotel will also increase. Those reasons behind the selection of the city as a location for research on the field of hotel business.

This study will specialize discussion in hotel business sector, particularly the 3-star hotel in Jakarta. Hotel is a business that provides a facility or service in terms of food, drinks, and room to sleep for people who travel and have the ability to pay according to the services received without special agreement (Sulastiyono, 2011). In Jakarta, the number of 3-star hotels in Jakarta experienced growth from 2010-2014 (Table I).

TABLE I. N NUMBER OF 3-STAR HOTEL IN JAKARTA 2010- 2014

\begin{tabular}{cc}
\hline Year & Number of 3-star Hotel \\
\hline 2010 & 46 \\
2011 & 48 \\
2012 & 56 \\
2013 & 66 \\
2014 & 77 \\
\hline \multicolumn{2}{c}{ a. Source: Jakarta Tourism \& Culture Office (2015) }
\end{tabular}

Although the number of 3-star hotel in Jakarta continues to grow from year to year, have sprung up in recent budget hotel in Jakarta. According to Roper \& Carmouche (1989) as cited in Jones (2002), budget hotels cannot be equated with hotels in general because there is a special aspect of segmentation is that $2 / 3$ of the budget hotels offer accommodation at the rate of $1 / 2$ star hotels of five-star hotel rates. Hotel budget is not trying to lure customers with a reason for the convenience factor. More budget hotels offering lower rates than the five-star hotel such as 3-star hotel, and the location is situated on the main streets.

Budget hotels in Jakarta are Amaris, Fave Hotel, Hotel Whiz, and Hotel Pop. The emergence of many budget hotels will be a challenge and a threat to the 3-star hotel. Kesuma (2013) states that the 3-star hotel is getting tough competition from budget hotel that keeps showing up in Jakarta and surrounding areas. According to Jamil \& Aryaty (2010) in Rahman \& Kamarulzaman (2012), increased competition in the service industry for causing a company to be very concerned in terms of acquiring and retaining customers. It identifies the importance of hotel marketers to create customer loyalty. Factors customer complaints is also the reason the research on 3 -star hotel, in addition to the emergence of budget hotels which add to the competition 3-star hotel. Based on observations to formulate research problems, customer complaints obtained various hotels throughout 2014 through the guest comment card.

In this study, researchers conducted a grouping of customer complaints by the dimensions service quality from Parasuraman, Zeithaml \& Berry (1985), namely reliability (ability to perform the promised service accurately), assurance (the knowledge and courtesy of employees, as well as the ability to inspire trust and confidence), tangibles (the appearance of physical facilities, equipment, personnel and written materials), empathy (care and attention companies give to the customer), and responsiveness (willingness to help customers and provide prompt service). Recapitulation guest comment card of the hotel services indicate that many customer complaints hotel, with supreme reason is reliability.

The number of customer complaints of 203 -star hotels in Jakarta area is very high, the number of 314 complaints in 2014. Based on the results obtained shown that the majority of customer complaints is the hotel in terms of reliability and tangible. According Odindo \& Delvin (2012) factors that cause failure in service can affect the customer loyalty, in terms of changing behavior (switching behavior) to leave the service providers that make customers feel dissatisfied (Odindo \& Delvin, 2012). If these factors are not rectified then it can affect the organization's reputation due to negative publicity by word of mouth (Williams et al., 2012) and on the profitability of the organization, in terms of declining profit (Memarbashi, 2012; Ongori, Iravo \& Munene, 2013; Mohammed and Rashid, 2012). These facts indicate that customer loyalty plays a key role for the sustainability of a business. For the 3-star hotel, customer loyalty also plays a significant role. Customer loyalty is how much the customer experience positive feelings and demonstrate behaviors that support a company or brand.

According to Kotler \& Armstrong (2006) in Kangogo, Musiega \& Mansyasi (2013), loyalty gained through the provision of superior service and consistent, so it is very unlikely that customer expectations are not met. Customer loyalty is contributing to the increased frequency of consumer purchase, quantity purchased, and can prevent the movement of consumers to competitors, and also contribute in terms of positive news by word of mouth (Li \& Green, 2012).

For a business hotel, customer loyalty plays a role in the purpose of retaining customers and improve competitiveness in the face of changing trends hotel industry (Schulz, 2012 in Kangogo, Musiega \&Mansyasi, 2013). Facts show that infidelity customers resulted in an average $30 \%$ of hotel customers will switch to another hotel and about $50 \%$ were categorized loyal hotel customers will spend $50 \%$ of spending to stay at another hotel (Deloitte, 2013). At the same time, hotel customers loyal to a hotel is also the hotel loyal customers of competitors that hotel.

In this study, customer loyalty is seen in two aspects, namely word-of-mouth and repurchase intention. In connection with the word-of-mouth, Litvin, Goldsmith \& Pan (2008) in Lu, Ye \& Law (2014) recommends aspect of word-of-mouth should be of great concern and a source of profitable service business like a hotel with a competitive environment tall one. Preaching by word of mouth is a special role for the company where the product offered is usually intangible and based on experience or confidence (Taghizadeh, Taghipourian, \& Khazaei, 2013). Communication word-of-mouth is a highly influential factor in consumer purchasing decisions and are often more powerful than any other promotional methods that can be used by marketers, especially for personal communication is considered as a source more trustworthy and reliable than the non-personal information (Hennig-Thurau, Gwinner \& Gremler, 2002; Zeithaml \& Bitner, 1996). Repurchase intention helpful for service providers in terms of studying the behavior of the customer decision making (Samin et al., 2012), reduce marketing costs, and increase profitability. 
Commitment is widely accepted as a vital component of a successful relationship (Kim \& Trail, 2011). Commitment is an enduring desire to continue the relationship and role in strengthening the bond between the customer and a product (Jahanshahi et al., 2011). Customer commitment gives effect to the service providers in terms of increasing sales, profit, and as evidence preservation trusts from customers.

Relationships that show high-level commitment has been proven to be more appreciated, more stable, has fewer conflicts, and proven in the case of higher level of cooperation and loyalty to the organization (Palmatier et al., 2006). It can be concluded that consumers who already have a commitment to a brand or product would be difficult to be replaced (Jahanshahi et al., 2011).

For pure business fields such as bank services, education, and health care, service quality becomes the dominant element in the evaluation of consumers. For the business that are a combination of services and physical products such as hotels and restaurants, the service quality can also be an important factor for evaluating customer (Zeithmal, Bitner \& Gremler, 2013).

In the tourism industry, service quality became one of the main attributes for tourists to choose a destination, accommodation and activities to do. One of the things that is of major concern in the service quality is customer satisfaction. In connection with efforts to achieve customer satisfaction, the challenges facing the tourism industry is the fact that the expectations of customers who changed a lot the last few years. Therefore, for service providers, satisfying customers is a challenge (Al-Zeidi, 2012).

\section{LITERATURE REVIEW}

\section{A. Service Quality}

For decades, many researchers have developed a service perspective (Zeithaml, Bitner, \& Gremler, 2009; RamsaranFowdar, 2007). Chang (2008) explains that the concept of service quality should be approached from the standpoint of customers because they may have different values, different basis of assessment, and under different circumstances. Parasuraman, Berry \& Zeithaml, (1990) states that service quality is an attribution extrinsic perceived by the customer experience of the service customer perceived through the service encounter. According Kumar, Scheer \& Steenkamp (1995), service quality is not only involved in the final product and services, but also engaged in the production and delivery process, so that the employee involvement in process redesign and commitment necessary to produce the final product or tourism services. Service quality dimensions used in this study is a pioneer dimensions according to the study of dimensions service quality from Parasuraman, Zeithaml \& Berry (1985). The results of the study found that there are five dimensions in service quality, that is reliability, responsiveness, assurance, empathy and tangibles (Zeithmal, Bitner \& Gremler, 2013). Tangibles are aspects of the display elements are physically, reliability is an aspect of performance that is reliable and accurate, responsiveness is the aspect of speed and ministration, assurance is the aspect of credibility, security, competence and courtesy, and empathy are aspects of ease of access, communication good, and the understanding of the consumer (Wirtz, Chew \& Lovelock, 2012).

To understand the gap in the service quality, built a model SERVQUAL as an analytical tool that can help managers to identify gaps between the variables that affect service quality that offer. This model most used by marketing researchers and scientists, although exploratory study and does not offer a method of clear measurement to measure gaps at different levels (Ghotbabadi, Baharun \& Feiz, 2012).

At first, they suggested ten dimensions service quality but after some initial study in 1985 , the number of dimensions to models service quality is reduced to five, reliability, assurance, tangibles, empathy, and responsiveness. SERVQUAL model is based on the difference between perception and expectations service quality through a five-dimensional (Ghotbabadi, Baharun \& Feiz, 2012). The list of questions posed to respondents include two parts, the 21 questions about customer expectations, then in session two asked again 21 it's the perception of the customer based on the experience of each individual after using the services of a service industry (Hoffman \& Bateson, 2011).

Results of previous studies found that hotel performance is strongly associated with service quality. Changes in the performance of the hotel to be a very important factor for the sake of an assessment of hotel services better. The study says there are four important aspects to improve the service quality is a hotel employee, service, prestige and guest facilities and other (Saleem \& Raja, 2014).

In the study Salehi \& Hanzei (2014) of the 4-star hotel in Tehran, from the questionnaire found that the dimensions responsiveness ranks fourth highest among the other dimensions. Customer perception as measured by SERVQUAL higher than their expectations. Customers are very satisfied in terms of the willingness of the hotel staff to help customers and provide prompt service. Results were consistent with Parasuraman, Zeithaml \& Berry (1985) that the response of the service provider is a major factor in determining customer satisfaction. Service quality can directly affect customer loyalty (Wendha, Rahyuda \& Suasana, 2013). On the other hand, affects the customer satisfaction and lead to customer loyalty, and ultimately make customers return to make a purchase (Wendha, Rahyuda \& Suasana, 2013).

The purpose of the study Lai (2014) was to evaluate the role of customer satisfaction, perceived value and commitment as a mediator in the relationship between service quality and customer loyalty at restaurants tea Hong Kong-style as fast food restaurants that provide a menu of European and Asian food. The results showed that the service quality has a positive effect on customer loyalty.

\section{B. Customer Loyalty}

In connection with customer loyalty, in general there are three definitions of loyalty (Baran, Galka \&Strunk, 2008). First, behavioral loyalty, second, and third affect loyalty, situation-specific models of loyalty. All three types are seen from two points to a person classified true loyalty, namely the 
power of affecting actions (strength of affect) and repeatedly consume (Baran, Galka \& Strunk, 2008). Customer loyalty refers to an act of consumers to the brand, services, vendors, or the location of service providers. Such measures may include customers who survive, news or positive recommendation by word of mouth, and a willingness to pay more (Lai, 2014).Thus, in order to maintain and improve occupancy level and profit of the company, management or hotel managers need to do a proper strategy in order to attract a new hotel. Not only attract a new hotel, but also maintain the existing hotel guest, given the strong competition and the fact that the hotel guests were categorized as loyal can be loyal to a competitor. In terms of trying to achieve the satisfaction of hotel guests were even exceed customer expectations, companies need to understand the diversity of objectives put priority guests staying at the hotel as a vacation, work, attend a conference, or maybe just visiting counterpart (Walker, 2009; Winahyuningsih, 2010). Customer satisfaction, trust, commitment and intimacy with service providers the opportunity to be a loyal customer (Iqbal, 2014).

It can be concluded that customer loyalty is customer awareness in identifying a business. Awareness identify the influence intention to repurchase, the amount of expenditure, the possibility of recommending to others, and even the desire to be part of the business (Cheng, 2011). In this study, customer loyalty will be measured in terms of word of mouth recommendations to family, friends and others (Cheng, 2011; Lai, 2014; Iqbal, 2014), and the frequency of use of services (repeat purchase)

Word-of-mouth is defined as communication from consumers to consumers about products and services (Taghizadeh, Taghipourian, \& Khazaei, 2013). The term of word-of-mouth refers to the manner in which consumers communicate informally about the experience, evaluation and recommendation of goods or services to other potential customers (Rizka \& Widji, 2013). Although awareness of consumer products largely improved through the role of the mass media, in many occasions the information by word of mouth is more effective in influencing the actual purchase decision (Hawkins \& Mothersbaugh, 2010). Word-of-mouth that positively refers to the action and intensity of the customers in terms of recommending a brand to others (Nyffenegger et al., 2015). Organization engaged in hotel paid great attention to the influence of preaching the word-of-mouth in interpersonal because the hotel offers a product that is not real, so it can only be evaluated after a perceived or experienced by customers (Lu, Ye \& Law, 2014).

In recommending and promoting a positive thing to a brand, Iqbal (2014) adds that the loyal customers who also make repeat purchases. As shown in previous studies, that the loyal customers who not only would recommend the services it receives to peers, but also willing to pay extra to enjoy the other products offered (Rizka \& Widji, 2013). In addition to aspects of word-of-mouth, customer loyalty is also measured from the aspect repurchase intention. Purchase Intention is what consumers think will be purchased. According to Long and Ching (2010) purchase intention can be defined what you want to purchase in the future. Samin et al., (2012) says repurchase intention is intended as a motivation for action in the future. This is consistent with the opinion of Chao-Chien and I-Han (2014), that the repurchase intention can be seen as an indicator of the purchase in the future. It can be concluded that the Customer repurchase intention is defined as an individual assessment to repurchase a product ( $\mathrm{Li} \&$ Hong, 2013).

According Li \& Hong (2013), two determinants of repurchase intention is confirmation and satisfaction. Research by Babagbale, Onwe \& Aghedo (2009), in the restaurant business such as McDonald's, consistency lead to the satisfaction of the dam is ultimately a decisive factor so that the customer bought back (Babagbale, Onwe \& Aghedo, 2009). Repurchase intention can be influenced by several factors, including the relationship quality.

Relationship quality has a positive influence on consumer intentions to buy. Hennig-Thurau \& Klee (1997) suggests that the relationship quality is a predictor of repeat purchase behavior. Relationship quality accounted for an average 52\% of the variance in purchase intent within 50 empirical studies in the context of consumer products. Loyalty is measured from the many repeat purchase behavior of a product and possibility for repeat purchases, customers can even become immune or resistant to competitor promotional activity services provider (Du \& Tang, 2014). Therefore in this study repurchase intention is the variable that will be seen in customer loyalty.

\section{Commitment}

Commitment is generally defined as the exchange of trust between the parties that consider the relationship that is being established is very important and can survive in the long term (Kim, 2008). Commitment can be described as a long-term orientation towards customer business relationship based on both emotional ties (Geyskens et al., 1996; Moorman, Zaltman \& Deshpande, 1992). Commitment reflects customer loyalty to a brand, in a good situation and unsatisfactory (Nyffenegger et al., 2015).

Mohammadian \& Karimpour (2014) adds that the loyal relationship between the customer and a brand that is also seen in the relationship emotionally as a result of the satisfaction experienced by customers in the past. In this research hypothesis, commitment refers to the agreement and the cooperative behavior of the consumer to the provider. Instead, commitment which negatively affects the tendency of consumers to abandon the services that have been used (Kim \& Trail, 2011).

Fullerton (2005) in Chen, Chen \& Yang (2010) that the commitment to the customer is the psychological power to connect customers to the organization. Quality of service and commitment positively associated when customers do business with the organization. It can be concluded that by providing quality services and customer satisfaction, the customer will have a commitment with the organization or the hotel.

Commitment can be divided into cognitive and affective commitment. Cognitive commitment arises in a situation of shortage of customer's alternatives and in customer's situation changes or differences to deal with high prices. Affective 
commitment associated with strong feelings of customers to a brand.

Both of these can explain the process the customer becomes loyal to a brand and the accompanying behaviors such as repetitive purchases (Mohammadian \& Karimpour, 2014).

Variable commitment in research Rahmani-Nejad, Firoozbakht \& Taghipoor (2014) stand alone to be tested in their influence on customer loyalty. It is motivated by an understanding of the commitment evolving from merely a construct that has a limited definition becomes a complex construct involving various components. The research proves that the commitment together with relationship mental image quality and a positive effect on customer loyalty. From the results of statistical tests $\mathrm{T}$ and the mean was found that the variable commitment to give a positive effect on customer loyalty in order all three, i.e. after customer satisfaction and mental image.

Based on the literature review, the conceptual model proposed is:

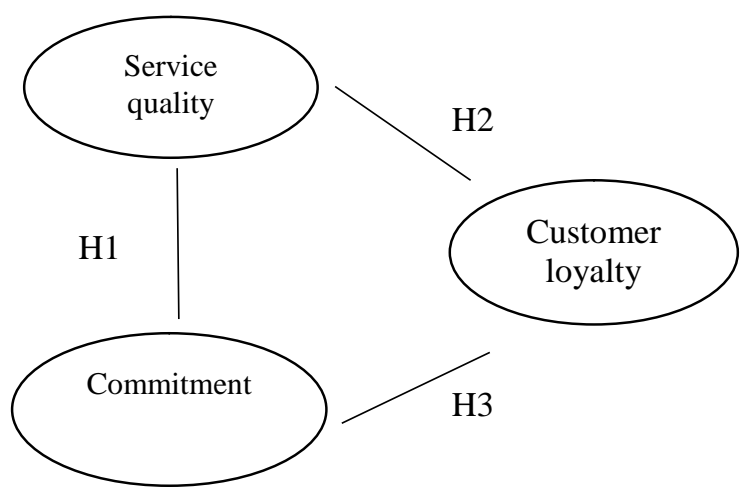

Fig. 1. Structural Model

The proposed hypotheses are:

H1: The service quality has a positive impact on customer loyalty

$\mathrm{H} 2$ : The service quality has a positive impact on commitment

H3: The commitment has a positive impact on customer loyalty

\section{METHODS}

The unit of analysis in this research is the organization, 3star hotels in Jakarta. Population 3-star hotel in Jakarta totaled 77 hotels spread across 5 regions. In a study conducted, 10 hotel was selected as a sample. The unit of observation in this study are individuals who become customers of 3-stars hotel. Customers 3-star hotels selected as samples in this study was that meet these criteria: (1) have the knowledge as the experience of being a customer at the 3-star hotel in Jakarta, (2) stayed at least 3 times in 3-star hotel in Jakarta in the past year, (3) the individual is selected to be the respondent is also being willing to participate.
The number of samples that are ideal for the analysis of SEM is 200 to 400 respondents. Based on the above theory, the number of questionnaires that will be distributed by the researchers was 350 questionnaires distributed evenly in 103 star hotel is the research samples so that each hotel deployed a total of 35 questionnaires.

The variables of this study were measured with a 5-point Likert scale. Below are the variables in this study together with the measuring instrument. Service quality is measured by the 21 statements were adapted from Salehi \& Hanzei (2013). Commitment is measured by six items according to the statement which was adapted from Elebiary (2012). Customer loyalty is measured using two dimensions of word of- mouth and repurchase intention. Dimensions of word-of-mouth was measured with 5 items statement adapted from Al.Bostanji (2013). Dimensions repurchase intention was measured using three items adapted from a statement that Chen \& Hsieh (2011). Each variable is operationalized in order to do thestatistical analyses. The sources of each adapted indicators are presented in Table II.

\section{TABLE II. VARIABLES AND OPERATIONAL INDICATORS}

\begin{tabular}{cll}
\hline $\begin{array}{c}\text { Variab } \\
\text { les }\end{array}$ & \multicolumn{1}{c}{ Indicators } & Sources \\
\hline & & $\begin{array}{l}\text { Salehi \& } \\
\text { Service }\end{array}$ \\
Q. Hotel has seen modern equipment & Hanzei
\end{tabular}

Quality Tangible:

b. Hotel amenities looks interesting

c. The appearance of the hotel employees to look neat

d. Brochures and pamphlets hotel looks interesting

Reliability a. Hotel employees keep thei promises within the time promised

b. Hotel employee to help guest show sincerity

c. The hotel staff did a great service from the start

d. Hotel employees provide services as promised

e. The hotel staff did nothing wrong in providing the service

Responsiv a. The hotel employees are informed appropriately when the service will be performed

b. The hotel employees give promp service

c. The hotel employees are always willing to help guest

d. The hotel employees are never too busy to help guest

Assurance a. Hotel employee behavior instills confidence in guests.

b. Guests feel safe in doing transactions with a hote employee.

c. The hotel employees are consistently polite.

d. The hotel employees have the knowledge to answer guests questions

Empathy: a. Hotel operating hours is convenient

b. The hotel employees give individual attention 
Table IV. Cont.

Always recommend this hotel to

\begin{tabular}{|c|c|c|c|}
\hline 1 & anyone who asked for advice & 0.863 & \\
\hline 2 & $\begin{array}{l}\text { Advise colleagues to stay at this } \\
\text { hotel }\end{array}$ & 0.866 & \\
\hline 3 & $\begin{array}{l}\text { Encourage colleagues to stay at } \\
\text { this hotel }\end{array}$ & 0.807 & \\
\hline 4 & $\begin{array}{l}\text { Said positive things about this } \\
\text { hotel to others }\end{array}$ & 0.797 & \\
\hline 5 & $\begin{array}{l}\text { Expressed the intention to stay } \\
\text { back at this hotel in the future }\end{array}$ & 0.806 & \\
\hline \multicolumn{2}{|c|}{ Repurchase Intention } & & 0.787 \\
\hline 6 & Willing to stay at this hotel again & 0.753 & \\
\hline 7 & $\begin{array}{l}\text { Do not want to stay at another } \\
\text { hotel }\end{array}$ & 0.889 & \\
\hline 8 & $\begin{array}{l}\text { If given the choice, would choose } \\
\text { this hotel brands }\end{array}$ & 0.868 & \\
\hline
\end{tabular}

\section{B. Descriptive Statistics}

Table $\mathrm{V}$ provides a summary of the descriptive statistics for service quality, commitment and customer loyalty. As regards the measure of central tendency (mean values) of these factors, it appears that most of these values cluster around point four (somewhat agree) on the instrument scale and low standard deviation value (below 1.00). It is indicating that most of the respondents have a positive perception and relatively consistent regarding the service quality, commitment and customer loyalty.

\section{TABLE V. A SUMMARY OF DESCRIPTIVE STATISTICS}

\begin{tabular}{lll}
\multicolumn{1}{c}{ Construct } & Mean & Std.Deviation \\
\hline Service Quality & 3.820 & 0.779 \\
Commitment & 3.280 & 0.912 \\
Customer Loyalty & 3.525 & 0.885 \\
\hline
\end{tabular}

\section{Goodness-of-Fit}

Before testing the hypothesis, there should be a full analysis of structural equation model as a condition goodness-of-fit model. The results of the conformance test models with different types of measurements goodness-of-fit can be seen in the following table.

TABLE VI. GOODNESS-OF-FIT INDEX

\begin{tabular}{|c|c|c|c|c|}
\hline \multirow{2}{*}{\multicolumn{2}{|c|}{$\begin{array}{c}\text { Goodness-of-Fit } \\
\text { Measures }\end{array}$}} & \multicolumn{2}{|c|}{ Standard Indicators } & Result \\
\hline & & \multicolumn{2}{|c|}{ Absolute Fit Measures } & \\
\hline a. & $\begin{array}{l}\mathrm{X} \\
2\end{array}$ & $\mathrm{P}$ value $>0.05$ & $\begin{array}{l}437.500 \\
(\mathrm{P}=0.00)\end{array}$ & Marginal Fit \\
\hline b. & $\begin{array}{l}\mathrm{N} \\
\mathrm{C} \\
\mathrm{P}\end{array}$ & $\begin{array}{l}\text { Smaller values } \\
\text { indicating better } \\
\text { model fit }\end{array}$ & 122.5 & Marginal Fit \\
\hline c. & $\begin{array}{l}\text { G } \\
\text { FI }\end{array}$ & $\geq 0.90$ & 0.920 & Fit \\
\hline $\mathrm{d}$. & $\begin{array}{l}\mathrm{R} \\
\mathrm{M} \\
\mathrm{S} \\
\mathrm{R}\end{array}$ & $\begin{array}{l}\text { Smaller values } \\
\text { indicating better } \\
\text { model fit }\end{array}$ & 0.047 & Fit \\
\hline
\end{tabular}

Table VI. Cont.

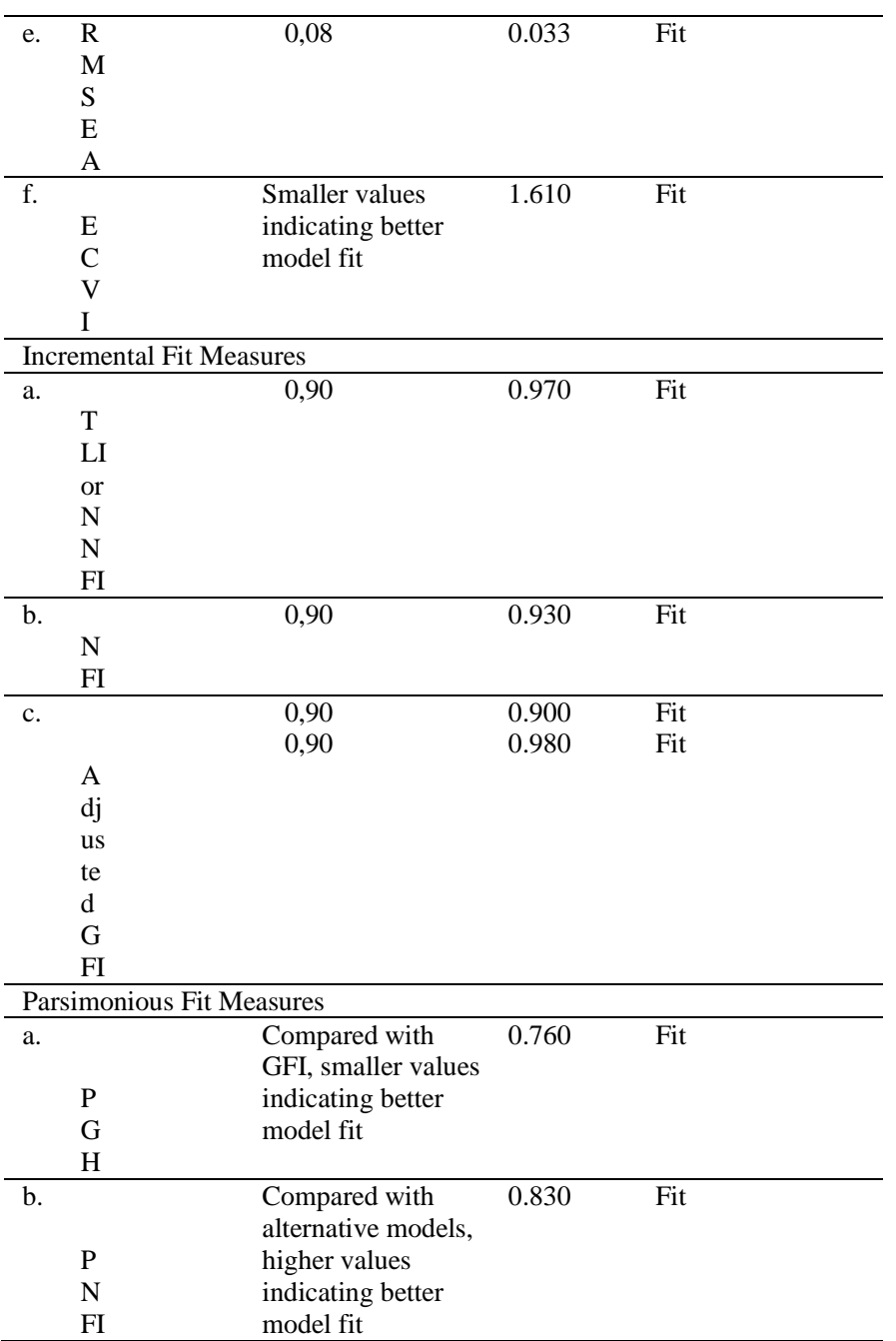

Note: NCP (Noncentrality parameter), GFI (Goodness-offit Index), RMSEA (Root Mean Square Error of Approximation), ECVI (Expected Cross Validation Index), TLI (Turki-Lewis Index), NNFI (Non Normed Fit Index), NFI (Normed Fit Index), PGFI (Parsimonious Goodness-of-Fit Index), PNFI (Parsimonious Normed-of-Fit Index).

\section{Results of Hypotheses Testing}

Hypothesis testing in this study used a significance level $(\alpha)$ $=0.05(\mathrm{t}$-table $=1,960)$.

TABLE VII. RESULTS OF HYPOTHESES TESTING

\begin{tabular}{llllll}
\hline & \multicolumn{1}{c}{ Path } & & $\begin{array}{c}\text { Standardized } \\
\text { Solution }\end{array}$ & $\begin{array}{c}\mathbf{t}- \\
\text { Value }\end{array}$ & $\begin{array}{l}\text { Data } \\
\text { Supporting } \\
\text { Hypotheses }\end{array}$ \\
\hline H1 & $\begin{array}{l}\text { Service Quality } \\
\text { Customer Loyalty } \\
\text { H2 }\end{array}$ & & 0.850 & 8.870 & Yes \\
Service Quality & - & 0.780 & 7.940 & Yes \\
H3 & $\begin{array}{l}\text { Commitment } \\
\text { Commitment } \\
\text { Customer Loyalty }\end{array}$ & -0.560 & 4.370 & Yes \\
\hline
\end{tabular}




\section{Hypothesis 1:}

There is a positive impact of service quality on customer loyalty. The results of the estimation parameters (standardized regression weight) of service quality on customer loyalty show 0.850 indicate a significant and positive direction. Then the values obtained $\mathrm{t}$-value $=8.870>\mathrm{t}$-table $=1.960$.

\section{Hypothesis 2:}

There is a positive impact the service quality on commitment. The results of the estimation parameters (standardized regression weight) of service quality on commitment show 0.780 indicate positive direction. Then the values obtained $\mathrm{t}$-value $=7.940>\mathrm{t}$-table $=1.960$

\section{Hypothesis 3:}

There is positive impact of commitment on customer loyalty. The test results of the estimation parameters (standardized regression weight) of commitment on customer loyalty show 0.560 indicates a significant and positive direction. Furthermore values obtained $t$-value $=4.370>\mathrm{t}$ table $=1.960$.

\section{E. Discussion}

There is a positive impact of service quality on customer loyalty. Increasingly hotel employees provide appropriate services, quickly and in accordance with the promised customer will recommend and provide a positive assessment of this hotel to the families and colleagues in need. The results of this study are supported by the results of previous studies of Poku, Zakari \& Soali (2013) which examined the 2-star hotels, 3 star Hotels and 4 Star Hotels in Ghana. This result is consistent with results of previous studies of Ivanauskiene \& Volungenaite (2014) which examines household retail chain in Lithuania, Latvia and Estonia. The results showed a threedimensional effect of service quality on customer loyalty is the personal Interaction, policy and product quality.

There is a positive impact of the service quality on commitment. The more employees look neat hotel, the hotel employees show sincerity to help the more customers feel an emotional bond, being concerned with the success of the hotel, there is a sense of belonging, to feel staying at the hotel more because of the need and hard to stay at another hotel. The study by Chen, Chen \& Yang (2010) aims to investigate the relationship between customers and e-tourism on service quality, satisfaction, trust, commitment and loyalty. In recent years, online travel service provider no longer face to face with customers from different regions. Therefore commitment into something that must be considered by the service provider. The results showed that the commitment is affected by service quality positively. Thus, the increased competition, service providers need to focus on not giving promises of services that cannot be met. This is also reinforced by the statement Fullerton (2005) in Chen, Chen \& Yang (2010) that the commitment to the customer is the psychological power to connect customers to the organization, the quality of service and commitment positively associated when customers do business with the organization.
There is a positive impact of commitment on customer loyalty. The more hotels forming an emotional bond that customers increasingly will choose this hotel brands and do not want to stay at another hotel. Relationships that show a high level of commitment has been shown to be more appreciated, more stable, has fewer conflicts, and proven in the case of higher level of cooperation and loyalty to the organization (Palmatier et al., 2006). It can be concluded that consumers or customers who have a Commitment to a brand or product would be difficult to be replaced (Jahanshahi et al., 2011). The results of this study are consistent with results of previous studies of the Rahmani-Nejad, Firoozbakht \& Taghipoor (2014) proves that the commitment together with relationship mental image quality and a positive effect on customer loyalty.

\section{F. Theoretical Implications}

Commitment appropriately used within the context of the 3star hotel to be able to increase customer loyalty, to see the positive influence of his relationship to customer loyalty.

\section{G. Managerial Implications}

Some suggestions are given for Sales and Marketing Manager, Front Office Manager, Food and Beverage Manager, Community Relations Manager and Restaurant Manager, as follows:

1) Improving the service quality by developing skills training on an ongoing basis for hotel employees in order to reduce errors are often made at the time of service to customers. Managers remind employees to carry out a notice to guests exactly when the service will be performed. This can be done during the entry briefing to and from work. For example: (1) when the customer is in the process of registration of rooms, customers are told exactly how long the rooms booked will be ready for occupancy, (2) when the guests order food and drinks at the Coffee Shop are told exactly how long the food manufacturing process and drinks will be ready to serve. Managers advise employees to take the time and do not leave the work area simultaneously. This is done so that customers feel comfortable and be able to rely on the hotel employees if they need help during a stay at the hotel.

2) Increasing commitment by doing outstanding service as a whole so as to exceed customer expectations. This can be done by way of greeting with the name of the customer, customs, food and beverage preferences of customers, so that customers feel more comfortable and will again use the services of the hotel and did not move to another hotel. Another thing you can do is the hotel management is a pair of photo or name of the customer on a glass or mug which is used and the customer can use for ordering drinks at the bar or lounge whenever they come to visit so that customers will have the ownership of the goods in the bar or lounge or even in the hotel.

3) Increasing customer loyalty by optimizing these two indicators, (1) word-of-mouth, the impression should be given must be attached to the customer. Things to do is Sales and 
Marketing Manager sent a birthday card or a cake on her birthday customers or provide meal vouchers invitations to regular guests who celebrate their anniversary. It can provide the deepest impression for customers and then be on the customer offering hotel services to colleagues and family. Another thing to do is to do a regular schedule greet customers at breakfast or dinner made by the Food and Beverage Manager. (2) Repurchase intention, preferably Front Office Manager or Food and Beverage Manger provides a discount card that can be used on arrival the following to stay, eat or drink at the coffee shop or spa so that customers will feel happy to come back in order to use price cuts. Other things that can be done is to provide a variety of amenities to guests in accordance with the length of stay. As for length of stay 1-2 days receive 1 fruit basket of fruit, 3-4 days to get a wide variety of snacks, more than 5 days to get a drink special.

\section{H. Limitations of the Study}

The study was only conducted at 3-star hotels in Jakarta. Research conducted focused on tangible, reliability, responsiveness, assurance, and empathy as indicators of service quality.

\section{Future Research}

For future research suggested to examine the tangible, reliability, responsiveness, assurance, and empathy as the dimensions of service quality. With the results mentioned above, the advice given is to conduct research to implement commitment on boutique hotel, budget hotel or by conducting research on other service industries such as spa, health club or restaurant. Second, the sample used in this study is to use the 3star hotel customers as a research object and conducted only in Jakarta. Further research can be done in the city or other island that has characteristics different respondents such as Bali, Sumatra, Kalimantan, Sulawesi, or other places, so that the next research will get better results generalization.

\section{CONCLUSION}

There is a positive influence of service quality on customer loyalty. They have a strong emotional attachment to the hotel that provides the right services, quickly, in accordance with promised and will promote it among friends, family and colleagues. There is a positive influence of the service quality on commitment. Hotel employees who look neat, show sincerity to help make customers feel an emotional bond, being concerned with the success of the hotel, have a sense of belonging, stayed at the hotel because of the need and hard to stay at another hotel. There is a positive influence of commitment oncustomer loyalty. Hotels that form a strong emotional $\mathrm{b}$ ond so customers will choose this hotel brands and do not want to stay at another hotel.

\section{REFERENCES}

Al.Bostanji, G. M. (2013). The Impact of Service Quality on Customers Loyalty A Study on five stars hotel's customers in Riyadh, KSA. European Journal of Business and Management, No. 5 (31).
Al-Zeidi, A. N. (2012). Exploring the Interrelationships among Operations Management Practices, Customer Perceptions of Service Quality, and Performance of Hotels. Thesis.

Babagbale, E. I., Onwe, O. \& Aghedo, C. A. (2009). Hospitality Sales And Marketing. HCM 237.

Victoria Island, Lagos, Nigeria: National Open University of Nigeria.

Badan Penanaman Modal dan Perijinan (2015). Profil Jakarta. http://www.bpmpjakarta.info/index.php/investasi-dijakarta/jakarta-baru, Retrieved June 30, 2015.

Badan Pusat Statistik (2015). Penduduk 15 Tahun ke Atas yang Bekerja Menurut Lapangan Pekerjaan

Perdagangan, Hotel dan Restoran Tahun 2010-2014. https://www.bps.go.id/index.php, Retrieved May 6, 2016.

Baran, R. J., Galka, R. J., \& Strunk, D. P. (2008). Principles of Customer Relationship Management..Mason, $\mathrm{OH} 45040$, USA: Thomson South-Western.

Chang, J. C. (2008). Taiwanese Tourists ${ }^{e e}$ perceptions of Service Quality on Outbound Guided Package

Tours: A Qualitative Examination of the SERVQUAL Dimensions. Journal of Vacation Marketing, Volume 15 (2), 164-178.

Chao-Chien \& I-Han, Chen (2014). A Study of the Effect of Experiential Marketing on Customer

Purchase Intention: Case Study of the Taipei International Sports Cycle Show. The Sport Journal, January 31, 2014.

Chen, H. H., Chen, S.C. \& Yang, C.C. (2010). The Impact of Service Quality and Relationship Quality on Customer Loyalty in E-tourism.

Chen, H.-S., \& Hsieh, T. (2011). A Study of Antecedents of Customer Repurchase Behaviors in Chain Store Sueprmarkets. Journal of International Management Studies, 6 (3), 1-11.

Cheng, S.I. (2011). Comparisons of Competing Models between Attitudinal Loyalty and Behavioral Loyalty. International Journal of Business and Social Science, 2 (10), 149-166.

Deloitte (2013). A Restoration in Hotel Loyalty: Developing a Blueprint for Reinventing Loyalty Programs. Deloitte Development LLC.

Du, Y. \& Tang, Y. (2014). A Literature Review on the Relationship Between Service Quality and Customer Loyalty. Business and Management Research, 3 (3), 2733.

Elebiary, A. M. (2012). Drivers of Guest Loyalty in the Hotel Industry in New Zeland: The Role of Staff Loyalty, Service Quality, Guest Satisfaction and Commitment, and Influence of Loyalty Programmes. New Zealand: The University of Waikato.

Fullerton, Gordon (2005). How commitment both enables and undermines marketing relationships. European Journal of Marketing, Vol. 39 Iss: 11/12, 1372 - 1388.

Geyskens, I., Steenkamp, J.E.M., Scheer, L.K. \& Kumar, N. (1996). The Effect of Trust and 
Interdependence on Relationship Commitment: A TransAtlantic Study, International. Journal of Research in Marketing, 13, 303-317.

Ghotbabadi, A. R., Baharun, R. \& Feiz, S. (2012). A Rreview of Service Quality Models. University Technology Malaysia (UTM). Langkawi Kedah: 2nd International Converence on Management.

Hanggara, Rendra (2015). Pembangunan Hotel Masih Prospektif. .

http://ekbis.sindonews.com/read/1027159/150/pembangunanhotel-masih-prospektif-1438137266/10, Retrieved July 2, 2016.

Hawkins, D. I. \& Mothersbaugh, D. L. (2010). Consumer Behavior: Bilding Marketing Strategy, 11th ed. New York: McGraw-Hill/Irwin.

Hennig-Thurau, T. \& Klee, A. (1997). The impact of customer satisfaction and relationship quality on customer retention: A critical reassessment and model development. Psychology and Marketing, 14 (8), 737764.

Hennig-Thurau, T., Gwinner, K. P. \& Gremler, D. D. (2002). Understanding Relationship Marketing Outcomes. Journal of Service Research, 4 (3), 230-247.

Hoffman, K. D. \& Bateson, J. E. (2011). Services Marketing: Concepts, Strategies, \& Cases, 4th ed. Mason, USA: South-Western.

Iqbal, A. (2014). Effect of Relationship Quality on Customer Loyalty. International Journal of Information, Business and Management, 6 (2), 41-52.

Ivanauskiene, N. \& Volungenaite, J. (2014). Relations between Service Quality and Customer Loyalty: An Empirical Investigation of Retail Chain Stores in Emerging Markets. American International Journal of Social Science, 3 (2), 113-120.

Jahanshahi, A. A., Gashti, M. A., Mirdamadi, S. A. \& Khaled, N. (2011). Study the Effects of Customer Service and Product Quality on Customer Satisfaction and Loyalty. International Journal of Humanities and Social Science, 1 (7), 253-260.

Jakarta Tourism \& Culture Office (2015). Number Of 3-Star Hotel In Jakarta 2010- 2014.

http://www.jakarta-tourism.go.id/, Retrieved May 6, 2016.

Jamil, B. \& Aryaty, A. (2010). The Influence of Relationship Quality on Loyalty in Service Sector. International Journal of Economics and Management, 4 (1), 81-100.

Jones, P. (2002). Introduction to Hospitality Operations: An Indispensable Guide to Industry. London: Cengage Learning Business Press

Kangogo, E. J., Musiega \& Mansyasi (2013). Effect of Customer Satisfaction on Performance of the Hotel Industry in the Western Tourism Circuit of Kenya. European Journal of Business and Management, 5 (14), 87-100.

Kesuma, M. (2013). Bisnis Perhotelan: Persaingan Bakal Makin Ketat. http://industri.bisnis.com/read/20130124/12/132993/bisnisperhotelan-persaingan-bakal-makin-ketat, Retrieved July 2, 2016.

Kim, Y. K. \& Trail, G. (2011). A Conceptual Framework for Understanding Relationships Between Sport

Consumers and Sport Organizations: A Relationship Quality Approach. Journal of Sport Management, 25, 57-69.

Kim, Y. K. (2008). Relationship Framework In Sport Management: How Relationship Quality Affects Sport Consumption Behaviors. Dissertation, University of Florida.

Kotler, P. \& Armstrong, G. (2006). Principles of Marketing. NJ: Pearson.

Kumar, N., Scheer, L. K. \& Steenkamp, J. E. M. (1995). The E ect of Supplier Fairness on Vulnerable Resellers. Journal of Marketing Research, 32 (1), 54-65.

Lai, I. K. (2014, December). The Roles of Value, Satisfaction, and Commitment in the Effect of Service Quality on Customer Loyalty in Hong Kong-Style Tea Restaurants.

Li, M. L. \& Green, R. D. (2012). A mediating influence on customer loyalty: The role of perceived value. Journal of Management and Marketing Research, 1-12.

Li, H. \& Hong, J. (2013). Factors Influencing Consumers' Online Repurchasing Behavior: A Review and Research Agenda. Scientific Research, 5, 161-166.

Litvin, S.W., Goldsmith, R.E. \& Pan, B. (2008). Electronic word-of-mouth in hospitality and tourism management. Tourism Management, 29 (3), 458-468.

Long, Y. L. \& Ching, Y. L. (2010). The Influence of Corporate Image, Relationship Marketing, and Trust on Purchase Intention: the Moderating Effects of Word-ofmouth, Tourism Review, 65 (3), 16-34.

Lu, Q., Ye, Q. \& Law, R. (2014). Moderating Effects of Product Heterogeneity between Online Word-of-Mouth and Hotel Sales. Journal of Electronic Commerce Research, 15(1), 1-12.

Memarbashi, S. (2012). Assessing customers' perception regarding service failure and recovery strategies and consumer future behavior in the restaurant industry; Evidence from Mashhad, Iran. Gazimağusa: Eastern Mediterranean University.

Mohammadian, M. \& Karimpour, Y. (2014). Identifying the Factors Influencing the Feeling of Love toward a Brand: The Adidas Case. Switzerland Research Park Journal, 103 (1), 94-122.

Mohammed, A. A. \& Rashid, B. B. (2012). Customer Relationship Management (CRM) in Hotel Industry: A framework Proposal on the Relationship among CRM Dimensions, Marketing Capabilities and Hotel Performance. International Review of Management and Marketing , 2 (4), 220-230.

Moorman, C., Zaltman, G. \& Deshpande, R. (1992). Relationships between Providers and Users of Market Research: The Dynamics of Trust within and between Organizations. Journal of Marketing Research, 29 (Aug), 314-329. 
Nyffenegger, B., Krohmer, H., Hoyer, W. D. \& Malaer, L. (2015). Service Brand Relationship Quality: Hot or Cold?. Journal of Service Research, 18 (1), 90-106.

Odindo, C. \& Delvin, J. (2012). Customer Satisfaction, Loyalty and Retention in Financial Services. Nothingham University Business School. Nothingham: Financial Services Research Forum.

Ongori, J. K., Iravo, M. \& Munene, C. E. (2013). Factors Affecting Performance Of Hotels And Restaurants In Kenya: A Case Of Kisii County. Interdisciplinary Journal Of Contemporary Research In Business, 4 (12), 897-928.

Palmatier, R. W., Dant, R. P., Grewal, D. \& Evans, K. R. (2006). Factors Influencing the Effectiveness of Relationship Marketing: A Meta-Analysis. Journal of Marketing, 70 (October), 136-53.

Parasuraman, A., Zeithaml, V. A. \& Berry, L.L. (1985). A Conceptual Model of Service Quality and Its Implications for Future Research. Journal of Marketing, Vol. 49, No. 4, 41-50.

Parasuraman, A., Berry, L.L. \& Zeithaml, V. A. (1990). Guidelines for Conducting Service Quality Research. Marketing Research, Dec. 90, Vol. 2 Issue 4, 34-44.

Poku, K., Zakari, M. \& Soali, A. (2013). Impact of Service Quality on Customer Loyalty in the Hotel

Industry: An Empirical Study from Ghana. International Review of Management and Business Research, 2 (2), 600-609.

Rahman, M. A. \& Kamarulzaman, Y. (2012). The Influence of Relationship Quality and Switching Costs on Customer Loyalty in the Malaysian Hotel Industry. Social and Behavioral Sciences, 62, 1023-1027.

Rahmani-Nejad, L., Firoozbakht, Z. \& Taghipoor, A. (2014). Service Quality, Relationship Quality and Customer Loyalty (Case Study: Banking Industry in Iran). Open Journal of Social Sciences, 2, 262-268.

Ramsaran-Fowdar, R.R. (2007). Developing a service quality questionnaire for the hotel industry in Mauritius. Journal of Vacation Marketing, Volume 13 (1), 19-27.

Rizka, M. \& Widji, A. (2013). Customer Loyalty the Effects of Service Quality and The Mediating Role of Customer Relationship Marketing Telkom Speedy in Jember Area. Society of Interdisciplinary Business Research, Vol 2 (1). 491-502.

Roper, A. \& Carmouche, R. (1989). Budget Hotels-A Case of Mistaken Identity? International Jpurnal of Contemporary Hospitality Management, 1 (1).
Samin, R., Muhammad, S. R., Firoozeh, F., Mahsa, H. \& Sanaz, E. (2012). A Conceptual Study on the Country of Origin Effect on Consumer Purchase Intention. Canadian Center of Science and Education, 8 (12), 205215.

Salehi, S. \& Hanzaei, A. M. (2014). Assessment of Customer Satisfaction in 4star Hotels of Parsian Hotel Chain in Tehran. Luleå University of Technology, Business Administration.

Saleem, H. \& Raja, N. S. (2014). The Impact of Service Quality on Customer Satisfaction, Customer Loyalty and Brand Image: Evidence from Hotel Industry of Pakistan. Journal of Business and Management, 16 (1), 117-122

Schulz, R.N. (2012). The effects of business image on customer retention in hotels in Eldoret, Kenya. European Journal of business and management, Vol. 4, No. 18.

Sulastiyono, Agus (2011). Manajemen Penyelenggaraan Hotel: Seri Manajemen Usaha Jasa Sarana Pariwisata dan Akomodasi. Bandung: Alfabeta

Taghizadeh, H., Taghipourian, M. J. \& Khazaei, A. (2013). The Effect of Customer Satisfaction on Word of Mouth Communication. Research Journal of Applied Sciences, Engineering and Technology, 5(8), 2569-2575.

Walker, J. R. (2009). Introduction to Hospitality. New Jersey: Pearson Prentice Hall.

Wendha, A. A., Rahyuda, I. K. \& Suasana, I. A. (2013). Pengaruh Kualitas Layanan Terhadap Kepuasan dan Loyalitas Pelanggan Garuda Indonesia di Denpasar. Jurnal Manajemen, Strategi Bisnis, dan Kewirausahaan, 7 (1), 19-28.

Williams, M., Buttle, F. \& Buggemann, S. (2012). Relating Word-of-Mouth to Corporate Reputation. Public Communication Review, 2 (1), 1-16.

Winahyuningsih, P. (2010). Pengaruh Kepercayaan dan Kualitas Pelayanan terhadap Kepuasan Konsumen pada Hotel Griptha Kudus. Jurnal Sosbud, Des 2010, 1-9.

Wirtz, V., Chew, P. \& Lovelock, C. (2012). Essentials of Services Marketing. Singapore: Pearson

Zeithaml, V. A. \& Bitner, M. J. (1996). Services Marketing. New York: McGraw-Hill.

Zeithaml, V.A., Bitner, M.J. \& Gremler, D.D. (2009) Services Marketing: Integrating Customer Focus Across the Firm, New York: Mcgraw-Hill.

Zeithmal, V. A., Bitner, M. J., \& Gremler, D. D. (2013). Services Marketing, 6th ed. New York: McGraw-Hill. 